\title{
Phylogenetic analysis of strains originally assigned to Bullera variabilis: descriptions of Bullera pseudohuiaensis sp. nov., Bullera komagatae sp. nov. and Bullera pseudoschimicola sp. nov.
}

1 Systematic Mycology and Lichenology Laboratory, Institute of Microbiology, Chinese Academy of Sciences, Beijing 100080, China

2 Japan Collection of Microorganisms, RIKEN (The Institute of Physical and Chemical Research), Wako, Saitama, 351-0198, Japan

\author{
Feng-Yan Bai, ${ }^{1}$ Masako Takashima ${ }^{2}$ and Takashi Nakase ${ }^{2}$ \\ Author for correspondence: Feng-Yan Bai. Tel: +86 106255 5692. Fax: + 861062560912. \\ e-mail: baify@sun.im.ac.cn
}

Twenty strains previously assigned to the species Bullera variabilis Nakase \& Suzuki were reclassified using a molecular taxonomic approach. The strains were regrouped first by nucleotide sequence comparison of the rDNA internal transcribed spacer (ITS) regions, including the 5.8S gene. Phylogenetic positions of $B$. variabilis strains with different ITS region sequences were then analysed based on their 185 rDNA sequences. The taxonomic status of the original Bullera variabilis strains was clarified further by DNA-DNA hybridization experiments. Of the $\mathbf{2 0}$ strains studied, five remained in the species B. variabilis, six strains were reassigned to the species Bullera mrakii and three novel species were proposed for eight of the nine remaining strains, namely Bullera pseudohuiaensis sp. nov. (one strain; type strain JCM 5984 ${ }^{\top}=$ AS 2.2203'), Bullera komagatae sp. nov. (one strain; type strain JCM 5983 ${ }^{\top}=$ AS $2.2202^{\top}$ ) and Bullera pseudoschimicola sp. nov. (six strains; type strain JCM $3915^{\top}=$ AS $2.2201^{\top}$ ). The remaining strain, JCM 6140, was closely related to $B$. pseudoschimicola. However, differences in ITS region sequences between strain JCM 6140 and strains of B. pseudoschimicola, and the intermediate DNA-DNA relatedness to representative strains of $B$. pseudoschimicola did not allow a definite taxonomic decision to be made for strain JCM 6140.

Keywords: Bullera variabilis, Bullera pseudohuiaensis sp. nov., Bullera komagatae sp. nov., Bullera pseudoschimicola sp. nov., phylogeny

\section{INTRODUCTION}

Bullera variabilis Nakase \& Suzuki (1987) was initially described to accommodate a group of yeast strains that formed ballistoconidia of various shapes. Heterogeneity of the species has been shown by markedly different electrophoretic enzyme patterns among strains studied. However, it has been difficult to separate clear-cut groups based on enzyme patterns or any other phenotypic characteristic.

The yeasts of this group are common inhabitants of plant materials. Since B. variabilis was established in

Abbreviation: ITS, internal transcribed spacer.

The GenBank accession numbers for the ITS region and 18S rDNA sequences of the strains determined in the present study are AF314965-AF314989 and AF314990-AF314999, respectively.
1987, a considerable number of ballistoconidiumforming yeast strains phenotypically similar or phylogenetically closely related to this species have been isolated from various countries, including China, Japan, New Zealand, Thailand and Vietnam (Nakase, 2000). Before novel strains can be accurately classified, it is necessary to redefine the species concept of $B$. variabilis and clarify the taxonomic status of the strains previously assigned to this species. Since it is difficult to reclassify $B$. variabilis strains by conventional yeast taxonomy, molecular phylogenetic approaches were used to resolve the problem.

\section{METHODS}

Yeast strains. The strains used are listed in Table 1. In addition to the 17 strains originally described as B. variabilis (Nakase \& Suzuki, 1987), all other strains listed under this 
Table 1. Selected physiological characters of the Bullera variabilis strains grouped by ITS region sequence comparison

$T_{\max }$, maximum growth temperature; + , positive; - , negative; L, latent; $l$, latent and weak; w, weakly positive.

\begin{tabular}{|c|c|c|c|c|c|c|c|c|}
\hline \multirow[t]{2}{*}{ Group } & \multirow[t]{2}{*}{ Strain } & \multirow[t]{2}{*}{ Source } & \multicolumn{4}{|c|}{ Assimilation of: } & \multirow{2}{*}{$\begin{array}{c}\text { Starch } \\
\text { formation }\end{array}$} & \multirow[t]{2}{*}{$\boldsymbol{T}_{\max }\left({ }^{\circ} \mathrm{C}\right)$} \\
\hline & & & Lactose & Erythritol & Glucitol & Ethylamine & & \\
\hline \multirow[t]{5}{*}{ I } & JCM $5275^{\mathrm{T}}$ & Dead leaf of Oryza sativa, Japan & - & - & + & - & + & $29-30$ \\
\hline & JCM 5276 & Dead leaf of Oryza sativa, Japan & - & - & + & - & + & $29-30$ \\
\hline & JCM 5277 & Dead leaf of Oryza sativa, Japan & - & - & + & - & + & $29-30$ \\
\hline & JCM 6137 & Straw of Oryza sativa, Japan & - & - & + & - & + & $30-31$ \\
\hline & JCM 7267 & Dead leaf of Miscanthus sinensis, Japan & - & - & + & - & + & $27-28$ \\
\hline IIa & $\mathrm{JCM} 5984^{\mathrm{T}}$ & Dead leaf of Sasa sp., Japan & - & - & $\mathrm{L}$ & + & + & $23-24$ \\
\hline \multirow[t]{6}{*}{ IIb } & JCM 5986 & Dead leaf of Sasa sp., Japan & l & $\mathrm{L}$ & - & - & - & $27-28$ \\
\hline & JCM 7265 & Dead leaf of Miscanthus sinensis, Japan & $\mathrm{L}$ & $\mathrm{L}$ & - & - & - & $27-28$ \\
\hline & JCM 7266 & Dead leaf of Miscanthus sinensis, Japan & $\mathrm{L}$ & $\mathrm{L}$ & - & - & - & $27-28$ \\
\hline & JCM 7491 & Sooty moulds on Pseudopanax arboreum, New Zealand & l & + & l & - & - & $28-29$ \\
\hline & JCM 7479 & Dead leaf of Miscanthus sinensis, Japan & l & l & - & - & - & $28-29$ \\
\hline & NB-94 & Dead leaf of Miscanthus sinensis, Japan & $l$ & l & - & - & - & $27-28$ \\
\hline IIIa & JCM $5983^{\mathrm{T}}$ & Dead leaf of Sasa sp., Japan & - & - & + & - & - & $24-25$ \\
\hline \multirow[t]{7}{*}{ IIIb } & JCM 3914 & Dead base of bamboo culm, Canada & - & $l$ & $\mathrm{~L}$ & - & - & 23-24 \\
\hline & JCM $3915^{\mathrm{T}}$ & Dead base of bamboo culm, Canada & - & w & + & - & - & $23-24$ \\
\hline & JCM 5985 & Dead leaf of Sasa sp., Japan & - & $\mathrm{w}$ & + & - & - & $26-27$ \\
\hline & JCM 7486 & Dead leaf of Vitis ficifolia var. lobata, Japan & - & - & - & - & - & $26-27$ \\
\hline & NB-143 & Dead leaf of Miscanthus sinensis, Japan & - & - & - & - & - & $26-27$ \\
\hline & NB-239 & Dead leaf of Majanthemum bifolium var. dilatatum, Japan & - & - & l & - & - & $26-27$ \\
\hline & JCM 6140 & Dead leaf of Magnolia grandiflora, Japan & - & - & - & - & +- & $29-30$ \\
\hline
\end{tabular}

name in the last edition of JCM Catalogue of Strains (Nakase, 1999) were included.

18S rDNA and internal transcribed spacer (ITS) region sequencing. Nucleotide sequences of small-subunit rDNA (18S rDNA) and internal transcribed spacer (ITS1 and ITS2) regions, including 5.8S rDNA, were determined according to Sugita \& Nakase (1999) with the following modifications: cycle sequencing was performed using the ABI BigDye cycle sequencing kit and samples were electrophoresed on an ABI PRISM 310 Genetic Analyzer.

Molecular phylogenetic analysis. Sequences of the $18 \mathrm{~S}$ rDNA and ITS regions determined in this study and reference sequences were aligned with the CLUSTAL W program (Thompson et al., 1994) and adjusted manually. The reference sequences were obtained from DDBJ, EMBL and GenBank, where they had been deposited by other authors (Sugita et al., 1999a; Suh \& Sugiyama, 1993; Suh et al., 1996a, b; Swann \& Taylor, 1993; Takashima \& Nakase, 1998, 1999; Van de Peer et al., 1992). The phylogenetic tree was constructed from the evolutionary distance data calculated from Kimura's two-parameter model (Kimura, 1980) using the neighbour-joining method (Saitou \& Nei, 1987). Sites where gaps existed in any of the aligned sequences were excluded. Bootstrap analyses (Felsenstein, 1985) were performed from 1000 random resamplings.

DNA-DNA reassociation. Crude DNA was extracted from ground freeze-dried cells using the methods of Raeder \& Broda (1985). DNA purification, DNA base composition determination and DNA-DNA reassociation were performed according to Takashima \& Nakase (2000).

\section{RESULTS AND DISCUSSION}

\section{Grouping of the $B$. variabilis strains by ITS region sequence comparison}

The complete ITS region (including 5.8S rDNA) sequences of all the $B$. variabilis strains used were determined first. A dendrogram was drawn by

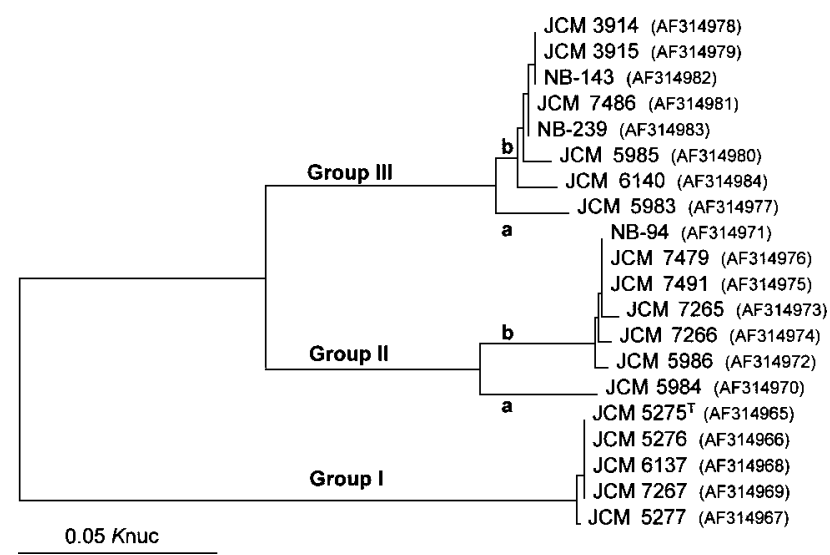

Fig. 1. Dendrogram drawn from neighbour-joining analysis based on ITS region sequences showing the grouping of the B. variabilis strains.

neighbour-joining analysis based on alignment of the ITS region sequences. The $20 \mathrm{~B}$. variabilis strains clearly separated into three groups corresponding to the three main clusters of the dendrogram (Fig. 1). Five strains, including B. variabilis JCM $5275^{\mathrm{T}}$, clustered into group I, seven into group II and the other eight were in group III. Groups II and III were further subdivided as depicted in Fig. 1.

The total lengths of ITS1-5.8S rDNA-ITS2 regions of the strains were as follows: group I, $389 \mathrm{nt}$; group IIa, $470 \mathrm{nt}$; group IIb, 488-490 nt; group IIIa, $493 \mathrm{nt}$; and group IIIb, 496-498 nt. The dramatic differences in ITS region length of group I from those of groups II and III indicated that the strains in group I were remarkably different from those in groups II and III. According to ITS region sequence similarity, group I 


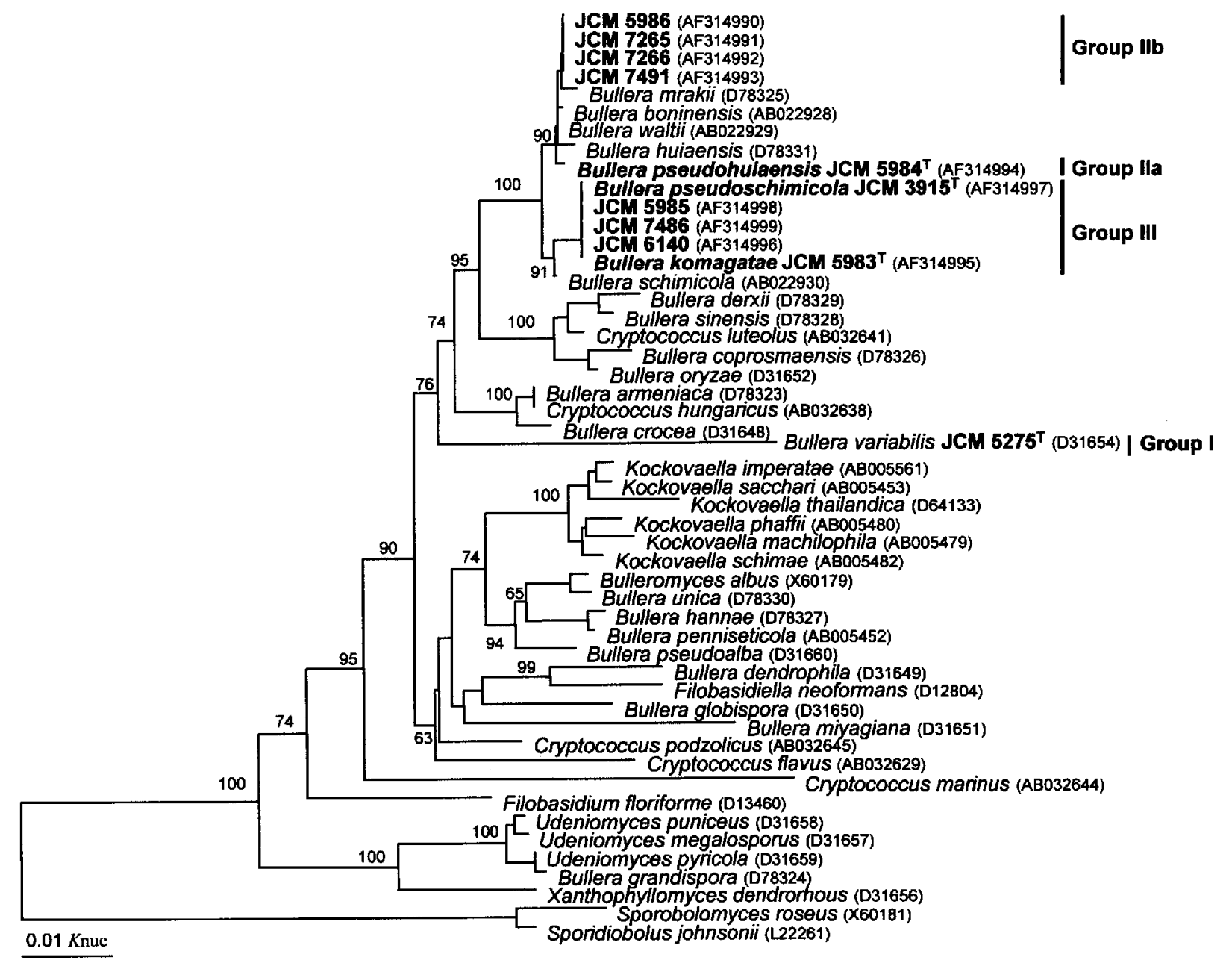

Fig. 2. Phylogenetic tree constructed from $18 \mathrm{~S}$ rDNA sequence alignment depicting the positions of representative $B$. variabilis strains. The phylogram was constructed by neighbour-joining analysis. Bootstrap percentages over $50 \%$ from 1000 bootstrap replicates are shown. The GenBank/EMBL/DDBJ accession numbers are indicated.

seemed to be homogeneous. Among the five strains in this group, four strains, including the type strain of $B$. variabilis, had identical ITS region sequences which differed from the fifth strain (JCM 5277) in only $1 \mathrm{nt}$. However, both groups II and III seemed to be heterogeneous. The two subgroups in each of these two groups differed from each other significantly in their ITS region sequences. Even within the same subgroups, especially in group IIIb, the ITS region sequences of the strains differed from each other to varying degrees, as indicated in Fig. 1.

Physiological profiles of the three groups recognized by ITS region sequence analysis were compared and differences were found in assimilation reactions of lactose, erythritol, glucitol and ethylamine, starch formation and maximum growth temperatures (Table 1). Strains in group I had almost identical assimilation patterns and similar maximum growth temperatures and could easily be distinguished from strains in the other two groups. In group II, strains in group IIb also had identical physiological characters, enabling them to be differentiated from the strain in group IIa. Strains in group III could be distinguished from strains in the other two groups, but were less homogeneous in their physiological characters. Their erythritol and glucitol assimilation reactions and maximum growth temperatures were divergent. The two subgroups IIIa and IIIb were indistinguishable in their physiological characters.

\section{Phylogenetic positions of the $B$. variabilis strains inferred from $18 \mathrm{~S}$ rDNA sequencing}

Heterogeneity of the B. variabilis strains was clearly demonstrated by their remarkable differences in ITS region sequences as mentioned above. To elucidate the phylogenetic relationships of the $B$. variabilis strains with one another and with other species in the genus Bullera and related xylose-containing basidiomycetous yeast taxa, $18 \mathrm{~S}$ rDNA sequences of representative $B$. variabilis strains were determined, namely those belonging to groups II and III which differ from each other in more than one nucleotide in ITS region 


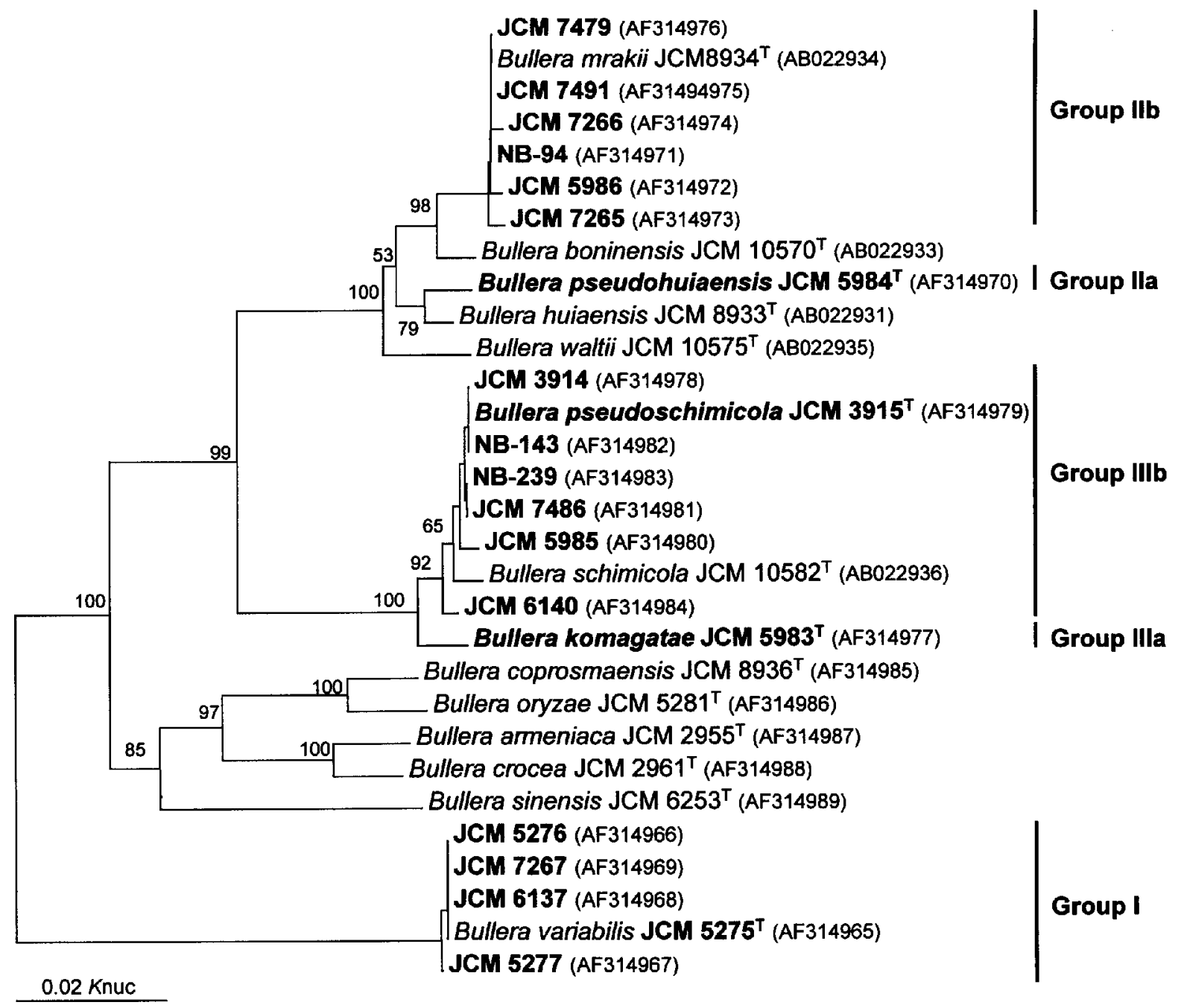

Fig. 3. Phylogenetic tree drawn from neighbour-joining analysis based on ITS region (including $5 \cdot 8 \mathrm{~S}$ rDNA) sequence alignment showing the relationships of the $B$. variabilis strains with closely related Bullera species. Bootstrap percentages over $50 \%$ from 1000 bootstrap replicates are shown. The GenBank/EMBL/DDBJ accession numbers are indicated.

sequences. A phylogenetic tree was constructed based on $18 \mathrm{~S}$ rDNA sequence alignment using neighbourjoining analysis (Fig. 2).

The 18S rDNA sequence of the type strain of $B$. variabilis (JCM 5275 $)$, which represents group I, has already been determined (Suh \& Nakase, 1995). The similarities in ITS region sequences and in physiological characters among the strains in group $\mathrm{I}$ as discussed above suggest that this group is homogeneous and can thus be assigned to the species $B$. variabilis. Therefore, no other strain was selected from group I for $18 \mathrm{~S}$ rDNA sequencing.

The groupings of the B. variabilis strains based on ITS region sequences were correspondingly separated in the phylogenetic tree based on 18S rDNA sequences (Fig. 2), which shows the species of Bullera separated into two main clades as already indicated by Suh et al. (1996a) and Takashima \& Nakase (1999). The representative strains of the three groups in this study are limited to one of the clades, which coincides with the 'Cryptococcus luteolus lineage' of Takashima \& Nakase (1999). B. variabilis JCM 5275 ${ }^{\mathrm{T}}$, representing group I, is basal to the clade and thus only distantly related to the others. Strains of group II clustered with Bullera mrakii, Bullera boninensis, Bullera waltii and Bullera huiaensis. The four strains of group IIb had identical 18S rDNA sequences and were closest to B. mrakii, whereas strain JCM $5984^{\mathrm{T}}$ had a unique sequence. All strains in group III had identical $18 \mathrm{~S}$ rDNA sequences and clustered with Bullera schimicola.

Phylogenetic relationships of the $B$. variabilis strains with closely related Bullera species demonstrated by ITS region sequence analysis

The ITS region sequences of the Buller a species in the clade containing the representative $B$. variabilis strains in the tree drawn from 18S rDNA sequences (Fig. 2) were then determined and aligned with those of all the 
Table 2. DNA-DNA relatedness of selected group Ilb strains of $B$. variabilis with the type strain of Bullera mrakii

\begin{tabular}{|c|c|c|c|c|c|c|}
\hline \multirow[t]{2}{*}{ Species/strain } & \multirow[t]{2}{*}{$\mathbf{G}+\mathbf{C}(\mathbf{m o l} \%)$} & \multicolumn{5}{|c|}{ Relative binding (\%) of DNA with JCM strain: } \\
\hline & & $8934^{\mathrm{T}}$ & 7491 & 5986 & 7266 & 7265 \\
\hline B. mrakii JCM $8934^{\mathrm{T}}$ & $43 \cdot 0$ & 100 & 93 & 82 & 64 & 65 \\
\hline Strain JCM 7491 & $42 \cdot 6$ & 91 & 100 & 77 & 56 & 57 \\
\hline Strain JCM 5986 & $42 \cdot 7$ & 91 & 92 & 100 & 61 & 67 \\
\hline Strain JCM 7266 & $42 \cdot 9$ & 61 & 63 & 58 & 100 & 87 \\
\hline Strain JCM 7265 & $43 \cdot 0$ & 60 & 68 & 57 & 82 & 100 \\
\hline
\end{tabular}

Table 3. DNA-DNA relatedness of strain JCM $5984^{\top}$ with closely related species

\begin{tabular}{|lcrrrrr|}
\hline \multirow{2}{*}{ Species/strain } & G + C (mol \%) & \multicolumn{5}{c|}{ Relative binding (\%) of DNA with JCM strain: } \\
\cline { 3 - 7 } & & $\mathbf{5 9 8 4 ^ { \mathrm { T } }}$ & $\mathbf{8 9 3 3}^{\mathrm{T}}$ & $\mathbf{8 9 3 4}^{\mathrm{T}}$ & $\mathbf{1 0 5 7 0}^{\mathrm{T}}$ & $\mathbf{1 0 5 7 5}^{\mathrm{T}}$ \\
\hline B. pseudohuiaensis JCM 5984 & $43 \cdot 9$ & 100 & 18 & 17 & 17 & 17 \\
B. huiaensis JCM 8933 & $44 \cdot 5$ & 31 & 100 & ND & ND & ND \\
B. mrakii JCM 8934 & $43 \cdot 0$ & 23 & ND & 100 & ND & ND \\
B. boninensis JCM 10570 & $43 \cdot 3$ & 22 & ND & ND & 100 & ND \\
B. waltii JCM 10575 & $43 \cdot 1$ & 31 & ND & ND & ND & 100 \\
\hline
\end{tabular}

ND, Not done.

B. variabilis strains used in the present study. A phylogenetic tree was drawn, with group I as the outgroup, according to the topology of the phylogenetic tree constructed from $18 \mathrm{~S}$ rDNA sequences. Four main clades were recognized in the phylogenetic tree drawn from the ITS region sequences and the original B. variabilis strains were distributed in three of them (Fig. 3).

\section{Taxonomic status of the strains in group II}

The strains in group II were included in the clade represented by $B$. mrakii (Fig. 3). The single strain in group IIa, JCM $5984^{\mathrm{T}}$, clustered close to $B$. huiaensis and the five strains in group IIb were located together with $B$. mrakii. The numbers of nucleotide differences in ITS region sequences among all the strains in this clade were calculated by pairwise comparison. The strains in group IIb differed from each other in 1-6 nt and differed from the type strain of B. mrakii in 0-3 nt. Data predict that the group IIb strains belong to $B$. mrakii. Strain JCM $5984^{\mathrm{T}}$ differed from the type strain of the closely related species $B$. huiaensis in $18 \mathrm{nt}$ $(3.8 \%)$, implying that JCM $5984^{\mathrm{T}}$ represents a distinct species.

DNA-DNA reassociation was performed between the type strain of B. mrakii and selected group IIb strains (Table 2). Strains JCM 5986 and JCM 7491 were clearly conspecific with $B$. mrakii because DNA homology values with the type strain of this species were $77-93 \%$. The other two strains, JCM 7265 and JCM 7266, had 82-87\% DNA similarity, though they differed in $5 \mathrm{nt}$ in ITS region sequences, but only had relatively low (56-68\%) DNA homology with the type strain of B. mrakii, JCM 5986 and JCM 7491. Data indicate that strains JCM 7265 and JCM 7266 represent a somewhat different population from that represented by the type strain of B. mrakii. Considering that the two strains differed from the type strain of $B$. mrakii in only 2-3 nt in the ITS region and that their DNA relatedness with $B$. mrakii was still within the range of the same species, it is thought that they should be assigned to the species $B$. mrakii. The morphological and physiological characters of the group IIb strains corresponded to those in the description of $B$. mrakii (Hamamoto \& Nakase, 1996).

As well as marked ITS region sequence differences, DNA homology of strain JCM $5984^{\mathrm{T}}$ with closely related species in the same clade was $17-31 \%$ (Table $3)$, which suggested that this strain represents an undescribed species, for which the name Bullera pseudohuiaensis sp. nov. is proposed.

\section{Taxonomic status of the strains in group III}

The $B$. variabilis strains in group III were located in a clade containing only one recently described species, B. schimicola (Sugita et al., 1999a) (Fig. 3). Group III strains differed from the type strain of $B$. schimicola in more than $18 \mathrm{nt}(3.6 \%)$ in the ITS region, implying 
Table 4. DNA-DNA relatedness of representative group III strains of $B$. variabilis with closely related species

\begin{tabular}{|c|c|c|c|c|c|c|c|}
\hline \multirow[t]{2}{*}{ Species/strain } & \multirow[t]{2}{*}{$\mathbf{G}+\mathbf{C}(\mathrm{mol} \%)$} & \multicolumn{6}{|c|}{ Relative binding (\%) of DNA with JCM strain: } \\
\hline & & $3915^{\mathrm{T}}$ & 5985 & 7486 & 6140 & $10582^{\mathrm{T}}$ & $5983^{\mathrm{T}}$ \\
\hline B. pseudoschimicola JCM $3915^{\mathrm{T}}$ & $44 \cdot 4$ & 100 & 67 & 72 & 59 & 56 & 39 \\
\hline Strain JCM 5985 & $44 \cdot 3$ & 66 & 100 & 81 & 61 & ND & 38 \\
\hline Strain JCM 7486 & $43 \cdot 9$ & 67 & 81 & 100 & 60 & 48 & 37 \\
\hline Bullera sp. JCM 6140 & $44 \cdot 7$ & 54 & 52 & 62 & 100 & 50 & 35 \\
\hline B. schimicola JCM $10582^{\mathrm{T}}$ & $43 \cdot 1$ & 50 & & 58 & 56 & 100 & 43 \\
\hline B. komagatae JCM $5983^{\mathrm{T}}$ & $44 \cdot 5$ & 35 & 39 & 46 & 45 & 29 & 100 \\
\hline
\end{tabular}

ND, Not done.

that the former can be genetically differentiated from B. schimicola. Although the representative strains in group III all had identical $18 \mathrm{~S}$ rDNA sequences, strain JCM $5983^{\mathrm{T}}$ in group IIIa differed from the strains in group IIIb by $18-22 \mathrm{nt}(3 \cdot 6-4 \cdot 4 \%)$ in the ITS region, suggesting that it represents a separate species. The taxonomic relationships of the seven strains in group IIIb showed by ITS region sequencing are not clear. Strain JCM 6140 differed from the other strains in the same subgroup by 7-11 nt in the ITS region and was on a separate branch in the neighbour-joining tree drawn from ITS region sequences (Fig. 3). However, the separation was not clear-cut; excluding JCM 6140, the strains in group IIIb differed from each other in $0-7 \mathrm{nt}$ in ITS region sequences.

DNA-DNA reassociation experiments were performed with strains having different ITS region sequences in group III and the type strain of B. schimicola (Table 4). Results confirmed that strain JCM 5983 represented a distinct species: DNA homology values with strains in group IIIb and with the type strain of $B$. schimicola were 29-46\%. The name Bullera komagatae sp. nov. is therefore proposed for strain JCM $5983^{\mathrm{T}}$.

The strains in group IIIb (including JCM 6140) had intermediate DNA-DNA homology values (48-58 \%) with the type strain of $B$. schimicola JCM $10582^{\mathrm{T}}$ (Table 4). However, as mentioned above, the former had remarkable and clear-cut nucleotide divergence $(3 \cdot 6-4 \cdot 4 \%)$ with the latter in ITS region sequences. Moreover, in the phylogenetic tree drawn from $18 \mathrm{~S}$ rDNA sequence comparison, the group IIIb strains were clearly separated from B. schimicola (Fig. 2). These sequence data suggest that the taxon or taxa represented by the group IIIb strains (including JCM 6140) are distinct from $B$. schimicola at species level.

Strains JCM 3915 ${ }^{\mathrm{T}}$, JCM 5985 and JCM 7486 in group IIIb were shown to be conspecific by their $66-81 \%$ DNA homology values. These three strains, together with JCM 3914, NB-143 and NB-239 (JCM 3914 and NB-143, and NB-239 have identical ITS region sequences with JCM $3915^{\mathrm{T}}$ and JCM 7486, respectively), represent a novel Bullera species, for which the name Bullera pseudoschimicola sp. nov. is proposed.
The taxonomic status of the remaining strain in group IIIb, JCM 6140, is not easy to determine according to the data obtained so far. It does not seem reasonable to classify JCM 6140 as $B$. pseudoschimicola because this strain is located in a distinct branch, separated from the other strains of group IIIb by B. schimicola in the phylogenetic tree drawn from ITS region sequence comparison (Fig. 3). However, its intermediate DNADNA homology values (52-62\%) with, and its unclear ITS region sequence divergences from, other strains of group IIIb make it difficult to make a definite taxonomic decision for JCM 6140. Therefore, JCM 6140 should be treated as Bullera sp. at present.

\section{The taxonomic significance of the ITS region sequences, electrophoretic patterns of enzymes and mycocins}

Because of its relatively higher rate of divergence compared to small-subunit or large-subunit rDNA, ITS region sequences have been considered to be a useful tool in resolving relationships among closely related taxa (Berbee et al., 1995; Fell et al., 2000; James et al., 1996; Oda et al., 1997; Waalwijk et al., 1996). Recent studies involving yeasts have found that ITS region sequence similarity is generally consistent with DNA-DNA relatedness and conspecific strains usually have fewer than $1 \% \mathrm{nt}$ differences in the ITS1 and ITS2 regions overall (Nagahama et al., 1999; Sugita et al., 1999a, b). The coincidence of the ITS region sequence similarity and DNA-DNA relatedness was observed among yeast strains used in the present study. However, up to approximately $2 \% \mathrm{nt}$ divergences in the ITS1 and ITS2 regions overall exist among some strains within each the species $B$. mrakii and B. pseudoschimicola sp. nov.

Boekhout et al. (1991) used six original B. variabilis strains in mating experiments. They found that mating only occurred between CBS $7347^{\mathrm{T}}\left(=\mathrm{JCM} 5275^{\mathrm{T}}\right)$ and CBS 7367 (= JCM 7267). The former is the type strain of $B$. variabilis and the latter is retained in this species because of its identical ITS region sequence with the former. In the present study, the remaining four $B$. variabilis strains used by Boekhout et al. (1991) were 
shown to belong to three other species: B. pseudoschimicola sp. nov. (CBS $7354=\mathrm{JCM}$ 3914), $B$. pseudohuiaensis sp. nov. $\left(\mathrm{CBS} 7364^{\mathrm{T}}=\mathrm{JCM} 5984^{\mathrm{T}}\right)$ and B. mrakii (CBS $7365=\mathrm{JCM} 7265 ; \mathrm{CBS} 7366=$ JCM 7266).

As mentioned previously, the heterogeneity of $B$. variabilis was first observed in the remarkable differences in electrophoretic patterns of enzymes among the strains originally assigned to this species (Nakase \& Suzuki, 1987). However, it is difficult to clearly correlate enzyme pattern similarities with ITS region sequence similarities among these strains. The present study showed that strains showing similarities below $30 \%$ in enzyme electrophoretic patterns may certainly be expected to represent different species. However, conspecific strains may have as low as $36 \%$ similarity, whereas strains belonging to different species may have as high as $69 \%$ similarity in enzyme patterns. A previous study (Bai et al., 1999) also indicated that yeast strains with different enzyme patterns may have very high DNA-DNA complementarities.

Sensitivity to mycocins (killer toxins) has been considered to be a useful tool in yeast taxonomy (Golubev, 1998). Mycocinogeny studies (Golubev \& Nakase, 1997, 1998) indicated that the killer-sensitive patterns of some strains originally classified as $B$. variabilis were different, implying that the species was heterogeneous. This observation has been confirmed here. However, the present study has shown that strains with different killer-sensitive patterns may be conspecific. For example, the two strains reclassified as B. mrakii in the present study, JCM 7479 and JCM 7491, have obviously different mycocin responses from each other and from the type strain of $B$. mrakii JCM $8934^{\mathrm{T}}$ (Golubev \& Nakase, 1998). The type strain of $B$. variabilis, JCM $5275^{\mathrm{T}}$, is insensitive to the Bullera sinensis mycocin, whereas strain JCM 6137, which has an ITS region sequence identical to that of JCM $5275^{\mathrm{T}}$, is weakly sensitive to this mycocin.

\section{Latin diagnosis of Bullera pseudohuiaensis Bai, Takashima \& Nakase sp. nov.}

In YM (Difco) liquido post dies 5 ad $17^{\circ} \mathrm{C}$, cellulae vegetativae ovoideae, ellipsoideae et longi-ellipsoideae, 2-4 $\times 5-8 \mu \mathrm{m}$. Anulus et sedimentum formantur. Post unum mensem ad $17^{\circ} \mathrm{C}$, anulus, insulae et sedimentum formantur. In agaro YM post unum mensem ad $17^{\circ} \mathrm{C}$, cultura gilvo-flavae, rugosa, nitida aut non-nitida, butyracea, margine glabra. Mycelium et pseudomycelium formantur. Ballistoconidia napiformia, turbinatae vel subglobosa, 3.5-4.5 × 4.0-5.0 $\mu \mathrm{m}$. Fermentatio nulla. Glucosum, galactosum, saccharosum, maltosum, cellobiosum, trehalosum, melibiosum, raffinosum, melezitosum, amylum solubile, D-xylosum, L-arabinosum, D-arabinosum (lente), D-ribosum (lente et exigue), Lrhamnosum (lente), galactitolum (exigue), glucitolum (lente), methyl $\alpha$-D-glucosidum (lente et exigue), salicinum (lente), glucono- $\delta$-lactonum, acidum 2-keto-

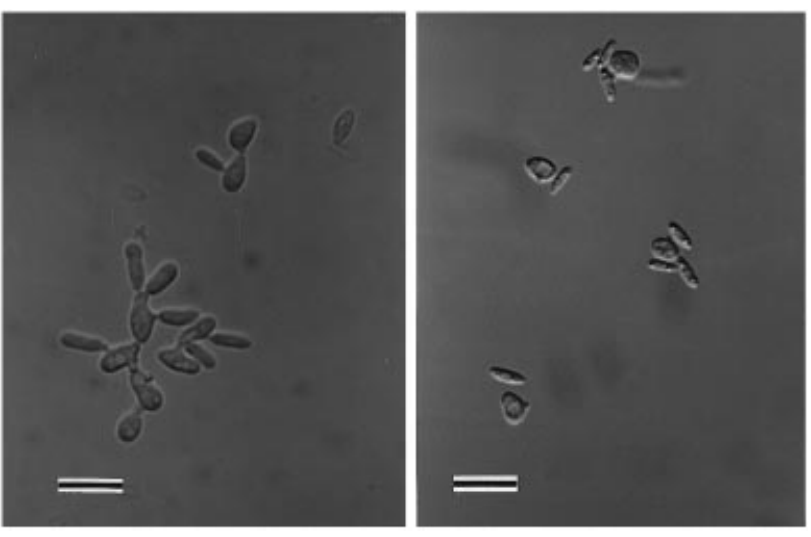

Fig. 4. B. pseudohuiaensis. (left) Vegetative cells grown in YM broth for $3 \mathrm{~d}$ at $17^{\circ} \mathrm{C}$. (right) Ballistoconidia produced on corn meal agar after $7 \mathrm{~d}$ at $20^{\circ} \mathrm{C}$. Bars, $10 \mu \mathrm{m}$.

gluconicum, acidum 5-ketogluconicum, acidum succinicum (lente et exigue) et inositolum (lente et exigue) assimilantur at non $\mathrm{L}-$ sorbosum, lactosum, inulin, ethanolum, glycerolum, erythritolum, ribitolum, D-mannitolum, acidum DL-lacticum nec acidum citricum. Ammonium sulfatum, ethylaminum (lente) et L-lysinum assimilantur at non kalium nitricum, natrum nitrosum nec cadaverinum. Ad crescentiam thiaminum necessarium sunt. Maxima temperatura crescentiae: 23-24 ${ }^{\circ} \mathrm{C}$. Materia amyloidea iodophila formantur. Urea finditur. Diazonium caeruleum B positivum. Proportio molaris $\mathrm{G}+\mathrm{C}$ in acido deoxyribonucleico: 43.9 mol \% (per HPLC). Ubiquinonum majus: Q-10. Xylosum in cellulis presens. Typus: isolatus ex folio Sasa sp. $\mathrm{JCM} 5984^{\mathrm{T}}$ (originaliter ut NB-192 ${ }^{\mathrm{T}}$ ) conservatur in collectionibus culturarum quas 'Japan Collection of Microorganisms’, Wako, Saitama sustentat.

\section{Description of Bullera pseudohuiaensis Bai, Takashima \& Nakase sp. nov.}

Bullera pseudohuiaensis (pseu.do.hui.a.en'sis. Gr. pseudes false; pseudohuiaensis referring to the close relationship of the species to Bullera huiaensis).

In YM broth, after $5 \mathrm{~d}$ at $17^{\circ} \mathrm{C}$, cells are oval, ellipsoidal or long ellipsoidal, $2-4 \times 5-8 \mu \mathrm{m}$. They occur singly or in clusters (Fig. 4, left). True mycelia are also present. An incomplete ring and a sediment are formed. After 1 month at $17^{\circ} \mathrm{C}$, an incomplete ring, a fragile sediment and islets are present. On YM agar, after 1 month at $17^{\circ} \mathrm{C}$, the streak culture is light yellow, butyrous, wrinkled, semi-shining to dull and has an entire margin. In Dalmau plate culture on corn meal agar, pseudomycelia and true mycelia are produced. Ballistoconidia are produced on corn meal agar. Usually they are napiform, turbinate or subglobose, 3.5-4.5 ×4.0-5.0 $\mu \mathrm{m}$ (Fig. 4, right). Fermentation is absent. Glucose, galactose, sucrose, maltose, cellobiose, trehalose, melibiose, raffinose, melezitose, 
soluble starch, D-xylose, L-arabinose, D-arabinose (delayed), D-ribose (delayed and weak), L-rhamnose (delayed), galactitol (weak), glucitol (delayed), methyl $\alpha$-D-glucoside (delayed and weak), salicin (delayed), glucono- $\delta$-lactone, 2-ketogluconic acid, 5-ketogluconic acid, succinic acid (delayed and weak) and inositol (delayed and weak) are assimilated. L-sorbose, lactose, inulin, ethanol, glycerol, erythritol, ribitol, Dmannitol, DL-lactic acid and citric acid are not assimilated. Ammonium sulfate, ethylamine hydrochloride (delayed) and L-lysine are assimilated. Potassium nitrate, sodium nitrite and cadaverine dihydrochloride are not assimilated. Thiamin is required for growth. Maximum growth temperature is $23-24{ }^{\circ} \mathrm{C}$. Starchlike substances are produced. Urease activity is positive. Diazonium blue B reaction is positive. The $\mathrm{G}+\mathrm{C}$ content of nuclear DNA is $43.9 \mathrm{~mol} \%$ as determined by HPLC. The major ubiquinone is Q-10. Xylose is present in the whole cell hydrolysate. The type strain, JCM $5984^{\mathrm{T}}$ (originally NB-192 ${ }^{\mathrm{T}}$ ), was isolated from a dead leaf of Sasa sp. collected from Suga-daira, Nagano Prefecture, Japan in May, 1985. This strain has also been deposited in the China General Microbiological Culture Collection Center, Institute of Microbiology, Chinese Academy of Sciences, Beijing, China, as AS $2.2203^{\mathrm{T}}$.

As shown in Table 1, B. pseudohuiaensis, represented by strain JCM $5984^{\mathrm{T}}$, is physiologically distinct from the other taxa represented by the remaining strains originally assigned to the species $B$. variabilis. In practice, Bullera pseudohuiaensis can be distinguished from its closely related species $B$. huiaensis by its inability to assimilate mannitol and cadaverine.

\section{Latin diagnosis of Bullera komagatae Bai, Takashima \& Nakase sp. nov.}

In YM (Difco) liquido post dies 5 ad $17^{\circ} \mathrm{C}$, cellulae vegetativae longi-ovoideae et longi-ellipsoideae, 2-4 $\times 4-8 \mu \mathrm{m}$. Anulus et sedimentum formantur. Post unum mensem ad $17^{\circ} \mathrm{C}$, anulus, insulae et sedimentum formantur. In agaro YM post unum mensem ad $17^{\circ} \mathrm{C}$, cultura subaurantiaca, glabra, nitida, butyracea, margine glabra. Mycelium et pseudomycelium formantur. Ballistoconidia napiformia, turbinatae vel polygoniae, 3-4×4-6 $\mu \mathrm{m}$. Fermentatio nulla. Glucosum, galactosum, saccharosum, maltosum, cellobiosum (lente), trehalosum, melibiosum, raffinosum, melezitosum, amylum solubile, D-xylosum, L-arabinosum, D-arabinosum (lente), D-ribosum (lente), L-rhamnosum (lente), galactitolum, D-mannitolum (lente), glucitolum, methyl $\alpha$-D-glucosidum (exigue), salicinum, glucono- $\delta$-lactonum, acidum 2-ketogluconicum, acidum 5-ketogluconicum, acidum succinicum (lente), acidum citricum (lente et exigue) et inositolum (lente) assimilantur at non L-sorbosum, lactosum, inulin, ethanolum, glycerolum, erythritolum, ribitolum nec acidum DL-lacticum. Ammonium sulfatum et L-lysinum assimilantur at non kalium nitricum, natrum nitrosum, ethylaminum nec cadaverinum. Ad crescentiam thiaminum necessarium

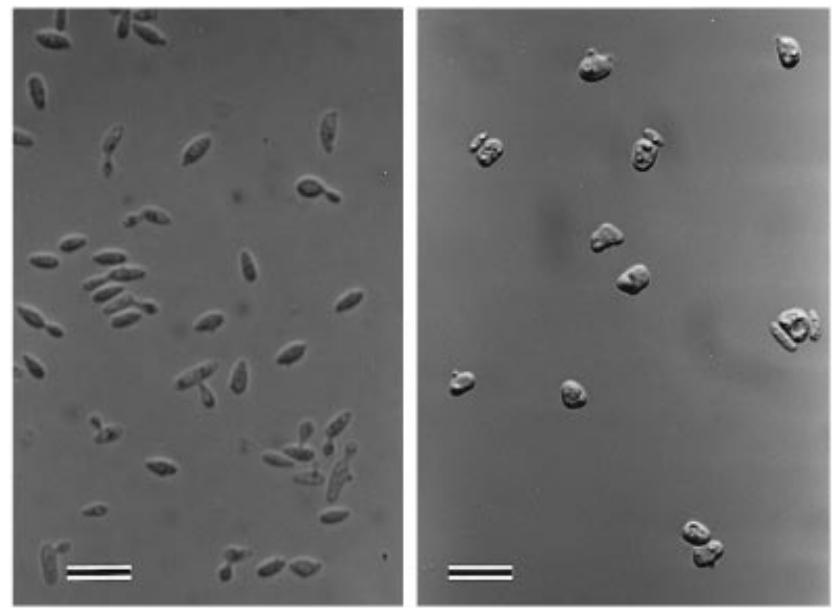

Fig. 5. B. komagatae. (left) Vegetative cells grown in YM broth for $3 \mathrm{~d}$ at $17^{\circ} \mathrm{C}$. (right) Ballistoconidia produced on corn meal agar after $7 \mathrm{~d}$ at $20^{\circ} \mathrm{C}$. Bars, $10 \mu \mathrm{m}$.

sunt. Maxima temperatura crescentiae: $24-25^{\circ} \mathrm{C}$. Materia amyloidea iodophila non formantur. Urea finditur. Diazonium caeruleum B positivum. Proportio molaris $\mathrm{G}+\mathrm{C}$ in acido deoxyribonucleico: $44.5 \mathrm{~mol} \%$ (per HPLC). Ubiquinonum majus: Q-10. Xylosum in cellulis presens. Typus: isolatus ex folio Sasa sp., JCM $5983^{\mathrm{T}}$ (originaliter ut $\mathrm{NB}-190^{\mathrm{T}}$ ) conservatur in collectionibus culturarum quas 'Japan Collection of Microorganisms', Wako, Saitama sustentat.

\section{Description of Bullera komagatae Bai, Takashima \& Nakase sp. nov.}

Bullera komagatae (ko.ma.ga.tae. M.L. komagatae in honour of Professor K. Komagata, Japan).

In YM broth, after $5 \mathrm{~d}$ at $17{ }^{\circ} \mathrm{C}$, cells are long oval to long ellipsoidal, $2-4 \times 4-8 \mu \mathrm{m}$. They occur singly or in clusters (Fig. 5, left). True mycelia are also present. A ring and a sediment are formed. After 1 month at $17^{\circ} \mathrm{C}$, a ring, a fragile sediment and islets are present. On YM agar, after 1 month at $17^{\circ} \mathrm{C}$, the streak culture is orange-yellow, butyrous, smooth, semi-shining and has an entire margin. In Dalmau plate culture on corn meal agar, pseudomycelia and true mycelia are produced. Ballistoconidia are produced on corn meal agar. They are napiform, turbinate, trigonal or tetragonal, 3-4×4-6 $\mu \mathrm{m}$ (Fig. 5, right). Fermentation is absent. Glucose, galactose, sucrose, maltose, cellobiose (delayed), trehalose, melibiose, raffinose, melezitose, soluble starch, D-xylose, L-arabinose, D-arabinose (delayed), D-ribose (delayed), L-rhamnose (delayed), galactitol, D-mannitol (delayed), glucitol, methyl $\alpha$-D-glucoside (weak), salicin, glucono- $\delta$-lactone, 2-ketogluconic acid, 5-ketogluconic acid, succinic acid (delayed), citric acid (delayed and weak) and inositol (delayed) are assimilated. L-Sorbose, lactose, inulin, ethanol, glycerol, erythritol, ribitol and DL- 
lactic acid are not assimilated. Ammonium sulfate and L-lysine are assimilated. Potassium nitrate, sodium nitrite, ethylamine hydrochloride and cadaverine dihydrochloride are not assimilated. Thiamin is required for growth. Maximum growth temperature is 24-25 ${ }^{\circ} \mathrm{C}$. Starch-like substances are not produced. Urease activity is positive. Diazonium blue $\mathrm{B}$ reaction is positive. The $\mathrm{G}+\mathrm{C}$ content of nuclear DNA is 44.5 mol $\%$ as determined by HPLC. The major ubiquinone is Q-10. Xylose is present in the whole cell hydrolysate. The type strain, JCM $5983^{\mathrm{T}}$ (originally NB-190 ${ }^{\mathrm{T}}$ ), was isolated from a dead leaf of Sasa sp. collected from Suga-daira, Nagano Prefecture, Japan, in May 1985. This strain has also been deposited in the China General Microbiological Culture Collection Center, Institute of Microbiology, Chinese Academy of Sciences, Beijing, China as AS 2.2202 ${ }^{\mathrm{T}}$.

\section{Latin diagnosis of Bullera pseudoschimicola Bai, Takashima \& Nakase sp. nov.}

In YM (Difco) liquido post dies 5 ad $17^{\circ} \mathrm{C}$, cellulae vegetativae longi-ovoideae et longi-ellipsoideae, 2-4 $\times 5-13 \mu \mathrm{m}$. Anulus et sedimentum formantur. Post unum mensem ad $17^{\circ} \mathrm{C}$, anulus, insulae et sedimentum formantur. In agaro YM post unum mensem ad $17^{\circ} \mathrm{C}$, cultura glivo-flavae aut rubro-flavae, glabra aut rugosa, nitida aut non-nitida, butyracea, margine glabra. Mycelium et pseudomycelium formantur. Ballistoconidia napiformia, turbinatae vel polygoniae, 4.0-5.0 $\times 6.0-7.5 \mu \mathrm{m}$. Fermentatio nulla. Glucosum, galactosum, saccharosum (fortasse lente), maltosum (fortasse lente), cellobiosum (fortasse lente), trehalosum (fortasse lente), melibiosum, raffinosum, melezitosum, amylum solubile, D-xylosum (fortasse lente), L-arabinosum (fortasse lente), D-arabinosum (fortasse lente), D-ribosum (lente), L-rhamnosum (fortasse lente), galactitolum (variabile), D-mannitolum (fortasse lente), glucitolum (variabile), methyl $\alpha$-D-glucosidum (lente vel exigue), salicinum (fortasse lente vel exigue), glucono- $\delta$ lactonum (fortasse lente), acidum 2-ketogluconicum, acidum 5-ketogluconicum, acidum succinicum (fortasse lente vel exigue), acidum citricum (lente et exigue) et inositolum (fortasse lente vel exigue) assimilantur at non L-sorbosum, lactosum, inulin, ethanolum, glycerolum, erythritolum (vel exigue), ribitolum (vel exigue) nec acidum DL-lacticum (vel exigue). Ammonium sulfatum et L-lysinum assimilantur at non kalium nitricum, natrum nitrosum (vel lente et exigue), ethylaminum nec cadaverinum. Ad crescentiam thiaminum necessarium sunt. Maxima temperatura crescentiae: $23-27^{\circ} \mathrm{C}$. Materia amyloidea iodophila non formantur. Urea finditur. Diazonium caeruleum $B$ positivum. Proportio molaris $\mathrm{G}+\mathrm{C}$ in acido deoxyribonucleico: 43.9-44.4 mol \% (per HPLC). Ubiquinonum majus: Q10. Xylosum in cellulis presens. Typus: JCM $3915^{\mathrm{T}}$, conservatur in collectionibus culturarum quas 'Japan Collection of Microorganisms', Wako, Saitama sustentat.
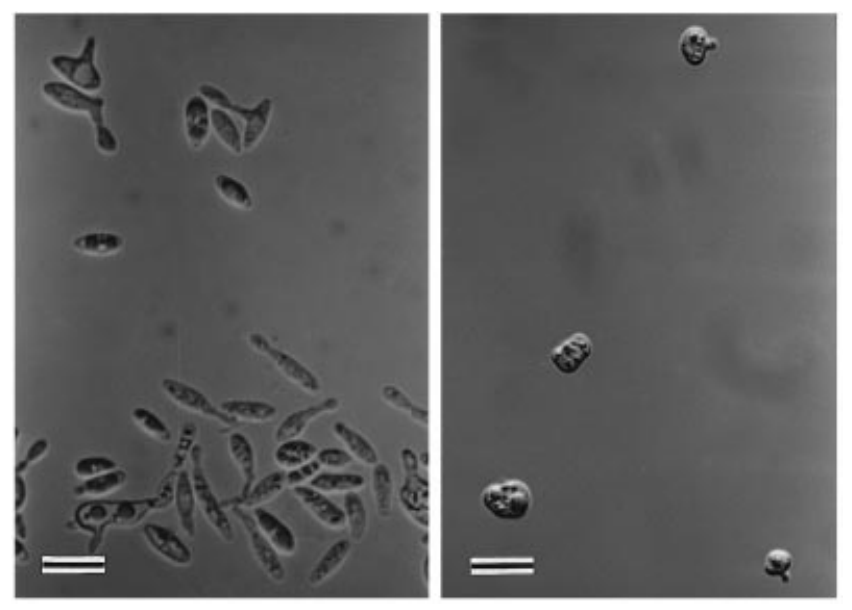

Fig. 6. B. pseudoschimicola JCM $3915^{\top}$. (left) Vegetative cells grown in $\mathrm{YM}$ broth for $3 \mathrm{~d}$ at $17^{\circ} \mathrm{C}$. (right) Ballistoconidia produced on corn meal agar after $7 \mathrm{~d}$ at $20^{\circ} \mathrm{C}$. Bars, $10 \mu \mathrm{m}$.

\section{Description of Bullera pseudoschimicola Bai, Takashima \& Nakase sp. nov.}

Bullera pseudoschimicola (pseu.do.schi.mi.co'la. Gr. pseudes false; pseudoschimicola referring to the close relationship of the species to Bullera schimicola).

In YM broth, after $5 \mathrm{~d}$ at $17^{\circ} \mathrm{C}$, cells are long oval, long ellipsoidal to club-shaped, $2-4 \times 5-13 \mu \mathrm{m}$. They occur singly or in clusters (Fig. 6, left). True mycelia are also present. Usually a ring and a sediment are formed. After 1 month at $17^{\circ} \mathrm{C}$, a ring, a fragile sediment and islets are present. On YM agar, after 1 month at $17^{\circ} \mathrm{C}$, the streak culture is light yellow, orange-yellow or reddish-yellow, butyrous, smooth or wrinkled, shining or semi-shining and has an entire margin. In Dalmau plate culture on corn meal agar, pseudomycelia and true mycelia are produced. Ballistoconidia are produced on corn meal agar. Usually they are napiform or turbinate. Polygonal, including trigonal, tetragonal or pentagonal, ballistoconidia are also produced, 4.0-5.0 $\times 6.0-7.5 \mu \mathrm{m}$ (Fig. 6, right). Fermentation is absent. Glucose, galactose, sucrose (or delayed), maltose (or delayed), cellobiose (or delayed), trehalose (or delayed), melibiose, raffinose, melezitose, soluble starch, D-xylose (or delayed), Larabinose (or delayed), D-arabinose (or delayed), Dribose (delayed), L-rhamnose (or delayed), galactitol (variable), D-mannitol (or delayed), glucitol (variable), methyl $\alpha$-D-glucoside (delayed or weak), salicin (or delayed or weak), glucono- $\delta$-lactone (or delayed), 2 ketogluconic acid, 5-ketogluconic acid, succinic acid (or delayed or weak), citric acid (delayed and weak) and inositol (or delayed or weak) are assimilated. LSorbose, lactose, inulin, ethanol, glycerol, erythritol (or weak), ribitol (or weak) and DL-lactic acid (or weak) are not assimilated. Ammonium sulfate and Llysine are assimilated. Potassium nitrate, sodium ni- 
trite (or delayed and weak), ethylamine hydrochloride and cadaverine dihydrochloride are not assimilated. Thiamin is required for growth. Maximum growth temperature is $23-27^{\circ} \mathrm{C}$. Starch-like substances are not produced. Urease activity is positive. Diazonium blue $\mathrm{B}$ reaction is positive. The $\mathrm{G}+\mathrm{C}$ content of nuclear DNA is $43.9-44.4 \mathrm{~mol} \%$ as determined by HPLC. The major ubiquinone is Q-10. Xylose is present in the whole cell hydrolysate. The type, JCM $3915^{\mathrm{T}}$, was isolated from the dead base of bamboo culm collected from Vancouver, Canada, in January, 1985. This strain has also been deposited in the China General Microbiological Culture Collection Center, Institute of Microbiology, Chinese Academy of Sciences, Beijing, China as AS $2.2201^{\mathrm{T}}$.

Phenotypically, B. komagatae and B. pseudoschimicola, originally $B$. variabilis strains in group III, are distinguishable from the species represented by the strains in groups I and II (Table 1). However, these two novel species are indistinguishable from each other by the morphological, physiological and biochemical characters examined in the present study. They differ slightly from their closely related species $B$. schimicola in L-sorbose assimilation reactions: the two novel species give negative results, whereas B. schimicola is weakly positive. In morphology, a considerable proportion of the ballistoconidia produced by strains of B. komagatae and B. pseudoschimicola were polygonal or irregularly shaped, whereas the ballistoconidia produced by $B$. schimicola were globose to napiform and polygonal or irregularly shaped ones were rarely observed.

\section{Redefinition of Bullera variabilis Nakase \& Suzuki}

The original description of $B$. variabilis was based on the 17 strains studied by Nakase \& Suzuki (1987). After reclassification of these strains in the present study, the demarcation of $B$. variabilis needs to be revised. According to the phenotypic characters of the five strains retained in $B$. variabilis, some physiological characters in the original description of this species are revised as follows: lactose and erythritol are not assimilated; galactitol and D-glucitol are assimilated; maximum growth temperature is $27-31{ }^{\circ} \mathrm{C}$; and starch-like substances are produced. $B$. variabilis was also originally described as forming variously shaped ballistoconidia. However, the strains forming polygonal ballistoconidia were limited to group III of the present study and were assigned to the species $B$. komagatae and B. pseudoschimicola. The strains remaining in the species $B$. variabilis usually form napiform, turbinate to subglobose ballistoconidia as shown in the original figure of the type strain of this species (Nakase \& Suzuki, 1987). The G + C contents of the type strain (JCM 5275 $)$ and two other strains (JCM 5276 and JCM 5277) of B. variabilis were reported to be $55.9-56.9 \mathrm{~mol} \%$ (Nakase \& Suzuki, 1987), which differ remarkably from those of the strains in groups II and III (42.7-44.7 mol \% ; Tables 2 , 3 and 4) which have been reassigned to other species.

\section{ACKNOWLEDGEMENTS}

This study was supported by the Special Coordination Funds of the Science and Technology Agency of the Japanese Government for the Asian Network on Microbial Research.

\section{REFERENCES}

Bai, F.-Y., Takashma, M. \& Nakase, T. (1999). Molecular phylogenetic studies on the Bensingtonia strain isolated from Yunnan, China. Mycosystema 18, 254-258.

Berbee, M. L., Yoshimura, A., Sugiyama, J. \& Taylor, J. W. (1995). Is Penicillium monophyletic? An evaluation of phylogeny in the family Trichocomaceae from $18 \mathrm{~S}, 5 \cdot 8 \mathrm{~S}$ and ITS ribosomal DNA sequence data. Mycologia 87, 210-222.

Boekhout, T., Fonseca, A. \& Batenburg-van der Vegte, W. H. (1991). Bulleromyces genus novum (Tremellales), a teleomorph for Bullera alba, and the occurrence of mating in Bullera variabilis. Antonie Leeuwenhoek 59, 81-93.

Fell, J. W., Boekhout, T., Fonseca, A., Scorzetti, G. \& StatzellTallman, A. (2000). Biodiversity and systematics of basidiomycetous yeasts as determined by large-subunit rDNA D1/D2 domain sequence analysis. Int $J$ Syst Evol Microbiol 50, 1351-1371.

Felsenstein, J. (1985). Confidence limits on phylogenies: an approach using the bootstrap. Evolution 39, 783-791.

Golubev, W. I. (1998). Mycocins (killer toxins). In The Yeasts, a Taxonomic Study, 4th edn, pp. 55-62. Edited by C. P. Kurtzman \& J. W. Fell. Amsterdam: Elsevier.

Golubev, W. I. \& Nakase, T. (1997). Mycocinogeny in the genus Bullera: taxonomic specificity of sensitivity to the mycocin produced by Bullera sinensis. FEMS Microbiol Lett 146, 59-64.

Golubev, W. I. \& Nakase, T. (1998). Mycocinogeny in the genus Bullera: killer activity of Bullera unica and intrageneric killer-sensitive relationships. Mikrobiologiya 67, 225-230 (in Russian).

Hamamoto, M. \& Nakase, T. (1996). Ballistosporous yeasts found on the surface of plant materials collected in New Zealand. The genera Bensingtonia and Bullera with descriptions of five new species. Antonie Leeuwenhoek 69, 279-291.

James, S. A., Collins, M. D. \& Roberts, I. N. (1996). Use of an rRNA internal transcribed spacer region to distinguish phylogenetically closely related species of the genera Zygosaccharomyces and Torulaspora. Int J Syst Bacteriol 46, 189-194.

Kimura, M. (1980). A simple method for estimating evolutionary rate of base substitutions through comparative studies of nucleotide sequences. J Mol Evol 16, 111-120.

Nagahama, T., Hamamoto, M., Nakase, T. \& Horikoshi, K. (1999). Kluyveromyces nonfermentans sp. nov., a new yeast species isolated from the deep sea. Int J Syst Bacteriol 49, 1899-1905.

Nakase, T. (1999). JCM Catalogue of Strains, 7th edn. Tokyo: Toppan.

Nakase, T. (2000). Expanding world of ballistosporous yeasts: distribution in the phyllosphere, systematics and phylogeny. $J$ Gen Appl Microbiol 46, 189-216.

Nakase, T. \& Suzuki, M. (1987). Bullera variabilis, a new species of yeast with uniquely-shaped ballistospores isolated from various plant materials. J Gen Appl Microbiol 33, 343-354.

Oda, Y., Yabuki, M., Tonomura, K. \& Fukunaga, M. (1997). Reexamination of yeast strains classified as Torulaspora debrueckii (Lindner). Int J Syst Bacteriol 47, 1102-1106. 
Raeder, U. \& Broda, P. (1985). Rapid preparation of DNA from filamentous fungi. Lett Appl Microbiol 1, 17-20.

Saitou, N. \& Nei, M. (1987). The neighbor-joining method: a new method for reconstructing phylogenetic trees. Mol Biol Evol 4, 406-425.

Sugita, T. \& Nakase, T. (1999). Non-universal usage of the leucine CUG codon and the molecular phylogeny of the genus Candida. Syst Appl Microbiol 22, 79-86.

Sugita, T., Canete-Gibas, C. F., Takashima, M. \& Nakase, T. (1999a). Three new species of Bullera isolated from leaves in the Ogasawara Islands. Mycoscience 40, 491-501.

Sugita, T., Nishikawa, A., Ikeda, R. \& Shinoda, T. (1999b). Identification of medically relevant Trichosporon species based on sequences of internal transcribed spacer regions and construction of a database for Trichosporon identification. J Clin Microbiol 37, 1985-1993.

Suh, S.-O. \& Nakase, T. (1995). Phylogenetic analysis of the ballistosporous anamorphic genera Udeniomyces and Bullera, and related basidiomycetous yeasts, based on 18S rDNA sequence. Microbiology 141, 901-906.

Suh, S.-O. \& Sugiyama, J. (1993). Phylogeny among the basidiomycetous yeasts inferred from small subunit ribosomal DNA sequence. J Gen Microbiol 139, 1595-1598.

Suh, S.-O., Takashima, M., Hamamoto, M. \& Nakase, T. (1996a). Molecular phylogeny of the ballistoconidium-forming anamorphic yeast genus Bullera and related taxa based on small subunit ribosomal DNA sequences. J Gen Appl Microbiol 42, 501-509.

Suh, S.-O., Takematsu, A., Takashima, M. \& Nakase, T. (1996b). Molecular phylogenetic study on stalked conidium-forming yeasts and related basidiomycetous yeast taxa based on 18S rDNA sequences. Microbiol Cult Coll 12, 79-86.

Swann, E. C. \& Taylor, J. W. (1993). Higher taxa of basidiomycetes: an $18 \mathrm{~S}$ rRNA gene perspective. Mycologia 95, 923-936.

Takashima, M. \& Nakase, T. (1998). Bullera penniseticola sp. nov. and Kockovaella sacchari sp. nov., two new yeast species isolated from plants in Thailand. Int J Syst Bacteriol 48, 1025-1030.

Takashima, M. \& Nakase, T. (1999). Molecular phylogeny of the genus Cryptococcus and related species based on the sequences of $18 \mathrm{~S}$ rDNA and internal transcribed spacer regions. Microbiol Cult Coll 15, 35-47.

Takashima, M. \& Nakase, T. (2000). Four new species of the genus Sporobolomyces isolated from leaves in Thailand. Mycoscience 41, 65-77.

Thompson, J. D., Higgins, D. G. \& Gibson, T. J. (1994). CLUSTAL $\mathrm{W}$ : improving the sensitivity of progressive multiple sequence alignment through sequence weighting, position-specific gap penalties and weight matrix choice. Nucleic Acids Res 22, 4673-4680.

Van de Peer, Y., Hendriks, L., Goris, A., Neefs, A., Vancanneyt, M., Kersters, K., Berny, J. F., Hennebert, G. L. \& De Wachter, R. (1992). Evolution of basidiomycetous yeasts as deduced from small ribosomal subunit RNA sequences. Syst Appl Microbiol 15, 250-258.

Waalwijk, C., de Koning, J. R. A., Baayen, R. P. \& Gams, W. (1996). Discordant groupings of Fusarium spp. from section Elegans, Liseola and Dlaminia based on ribosomal ITS1 and ITS2 sequences. Mycologia 88, 361-368. 